Original Article

Artigo Original

Luiza Augusta Rossi-Barbosa ${ }^{1}$ Ana Cristina Côrtes Gama² Antônio Prates Caldeira ${ }^{3}$

Keywords

Voice

Voice disorders

Health promotion

Faculty

Speech Language Pathology and Audiology

Descritores

Voz

Distúrbios da Voz

Promoção da Saúde

Docentes

Fonoaudiologia
Correspondence address:

Luiza Augusta Rosa Rossi-Barbosa

Rua São Marcos, 115, Todos os Santos,

Montes Claros (MG), Brazil,

CEP: 39400-128.

E-mail: luiza.rossi@unimontes.br

Received: $12 / 26 / 2013$

Accepted: $12 / 12 / 2014$

CoDAS 2015;27(2):170-7

\section{Association between readiness for behavior change and complaints of vocal problems in teachers}

\author{
Associação entre prontidão para mudanças de \\ comportamento e queixa de disfonia em professores
}

\begin{abstract}
Purpose: To verify the association between readiness to behavioral change and self-reported vocal problems of teachers in schools from the municipal education network of Montes Claros, Minas Gerais, Brazil. Methods: The URICA-VOICE scale was used to measure the motivational stages of 138 teachers. Readiness to change was the variable outcome, whereas the independent variables referred to sociodemographic, economic, occupational, lifestyle, general health, and teacher's own voice factors. Results: The majority $(59.4 \%)$ of teachers were in the pre-contemplation stage of the URICA-VOICE scale. The variables use of medication, perception of voice failure, and demand for speech and language therapy were retained for the final model. Conclusion: The low readiness to change showed the need for increased awareness of the risks and benefits related to the voice and general health. The results can provide public health intervention strategies that deal with individuals at various stages in the decision-making process.
\end{abstract}

\section{RESUMO}

Objetivo: Verificar a associação entre prontidão para mudanças de comportamento e queixa de disfonia autorreferida pelas professoras da rede municipal de ensino de Montes Claros, Minas Gerais, Brasil. Métodos: Foi aplicada a escala URICA-VOZ para a mensuração dos estágios motivacionais em 138 professoras. A prontidão para mudança constituiu a variável desfecho e as variáveis independentes se referiram a questões sociodemográficas, econômicas, ocupacionais, estilo de vida, saúde geral e sobre a própria voz. Resultados: A maioria $(59,4 \%)$ se encontrava no estágio de pré-contemplação da escala avaliada. As variáveis que permaneceram associadas à mudança comportamental quanto à voz foram o uso de medicamento, a percepção de falha na voz e a procura por tratamento fonoaudiológico. Conclusão: A baixa prontidão para mudança sugere a necessidade de conscientização quanto aos riscos do mau uso e abuso da voz e benefícios em relação à saúde geral e vocal. Os resultados obtidos poderão fornecer estratégias para intervenções de saúde pública ao lidar com as pessoas em diferentes estágios do processo de tomada de decisão.
Study carried out in Graduate Program in Health Sciences, Universidade Estadual de Montes Claros UNIMONTES - Montes Claros (MG), Brazil.

(1) Department of Odontology, Universidade Estadual de Montes Claros - UNIMONTES - Montes Claros (MG), Brazil.

(2) Speech Language Pathology and Audiology Department, School of Medicine, Universidade Federal de Minas Gerais - UFMG - Belo Horizonte (MG), Brazil.

(3) Graduate Program in Health Sciences, Universidade Estadual de Montes Claros - UNIMONTES - Montes Claros (MG), Brazil.

Financial support: Fundação de Amparo à Pesquisa do Estado de Minas Gerais - FAPEMIG.

Conflict of interests: nothing to declare. 


\section{INTRODUCTION}

Health promotion is a process that aims to increase the capacity of individuals and communities to control and improve their own health, which is essential for building a culture of wellness, self-care, and quality of life ${ }^{(1)}$. There are several health promotion theories, and the majority come from behavioral and social sciences because of the practice of focusing on the behavior of individuals and how society is organized ${ }^{(2)}$. The most commonly used theories between 2000 and 2005 were Transtheoretical Model, Social Cognitive Theory and the Belief Model in Health ${ }^{(3)}$.

The Transtheoretical Model, or Model of Change Phases, came up in the late 1970s and is based on the concept of stages of change to integrate processes and change principles resulting from the main intervention theories ${ }^{(4-6)}$. The Transtheoretical Model can be considered an important tool to help understand the health-related behavior change ${ }^{(4)}$.

On the basis of the Transtheoretical Model, scales were created to measure motivational stages, including University Rhode Island Change Assessment (URICA). This is a selfreport scale measure used generally for all types of problems ${ }^{(5,7)}$, and it is based on the stages of change containing four subscales: pre-contemplation, contemplation, action, and maintenance (Chart 1). The first two steps describe the development of intention to act, and the last two steps describe the process of putting the intention to change into practice ${ }^{(8)}$.

Important to remember that one cannot consider this model as linear and static because people do not go through stages sequentially; they can skip them or relapse, going in and out of stages $^{(9)}$, which leads to a dynamic evolution in spiral. Relapse is normal and expected when one is seeking a long-term behavior change ${ }^{(5)}$.

There is already an adapted version of URICA for people with dysphonia in Brazil, which is a questionnaire containing 32 items $^{(7)}$. Clinical and research utility of URICA is unquestionable ${ }^{(10)}$ as it helps understand the motivation of individuals regarding their capacity of changing health-related behavior ${ }^{(4)}$.
Among voice professionals, the category of teachers is the most vulnerable to the onset of dysphonia ${ }^{(11)}$. Therefore, the perception that a teacher has on his voice problem may be an important tool for the early detection of vocal problems ${ }^{(12)}$. Moreover, the speech therapist must value the patient's needs considering their own perspective, and it is essential to know about their sociodemographic status, individual characteristics, beliefs, and values ${ }^{(13)}$.

The literature lacks studies relating the Transtheoretical Model to speech disorders, which shows the importance of further research. So, the objective of this study was to assess the readiness for behavior change among teachers in the municipal school Montes Claros, Minas Gerais, who had complaints of dysphonia, and the association with sociodemographic, economic, occupational, lifestyle, general health, and other variables related to voice.

\section{METHODS}

This epidemiological, cross-sectional, analytical study was conducted in Montes Claros, northern Minas Gerais, Brazil. The city has about 370,000 inhabitants and is the main regional urban center in the State. The target population consisted of teachers of the first 5 years of primary education in municipal schools. According to data from the Municipal Department of Education, the network is composed of 640 teachers.

First, the sample calculation was performed by simple random sampling to estimate the prevalence of voice disorders. Calculation was set with a confidence level of $99 \%$, accuracy of $5 \%$, and estimated prevalence of self-reported voice alteration of $11.6 \%{ }^{(11)}$, so it was concluded that 196 teachers from municipal schools should be allocated in the study, considering possible losses. Male teachers were excluded due to their small number in the municipal network and anatomical differences of the larynx. Teachers not currently acting in the field and those of physical education were also excluded.

The data were collected in visits to schools. During recess time, the teachers were informed about the research

Chart 1. Stages of change, according to the Transtheoretical Model

\begin{tabular}{|c|c|c|c|}
\hline Concept & Definition & Possible strategies & Example \\
\hline \multicolumn{4}{|l|}{ Intention to act } \\
\hline 1. Pre-contemplation & $\begin{array}{l}\text { Resistance: do not consider the behavior } \\
\text { change hypothesis }\end{array}$ & $\begin{array}{l}\text { Increase awareness of the need for } \\
\text { change and customize information } \\
\text { about risks and benefits }\end{array}$ & $\begin{array}{l}\text { Do not intend to solve the } \\
\text { problem }\end{array}$ \\
\hline 2. Contemplation & Awareness of the problem & $\begin{array}{l}\text { Motivate or encourage to make } \\
\text { specific plans }\end{array}$ & $\begin{array}{l}\text { Thinking about solving the } \\
\text { problem }\end{array}$ \\
\hline \multicolumn{4}{|l|}{ Intention to change } \\
\hline 3. Action & $\begin{array}{l}\text { Determination to change behavior or } \\
\text { develop new ones. }\end{array}$ & $\begin{array}{l}\text { Help with feedback, solving problems, } \\
\text { social support, and reinforcement }\end{array}$ & $\begin{array}{l}\text { In process of solving the } \\
\text { problem }\end{array}$ \\
\hline 4. Maintenance & $\begin{array}{l}\text { Maintain behavior change over time; } \\
\text { prevention to relapse; consolidate the gains }\end{array}$ & $\begin{array}{l}\text { Help with coping, reminders, find } \\
\text { alternative avoiding slips, and relapse }\end{array}$ & Trying to get rid of the problem \\
\hline
\end{tabular}

Source: Adapted from the National Institutes of Health ${ }^{(9)}$ 
and the voluntary and anonymous character of participation. The self-administered questionnaire was structured and delivered in individual envelopes to teachers randomly chosen, and a date was set to collect it and clarify any doubts. Those who had vocal complaints were instructed to fill the URICA-VOICE questionnaire.

\section{Application of URICA-VOICE questionnaire}

We used the adapted version of the URICA-VOICE questionnaire with 32 items, whose questions concerning stages (pre-contemplation, contemplation, action, and maintenance) have possibilities of answers in scales such as five-point Likert scale, as oriented by the Health and Addictive Behaviors: Investigating Transtheoretical Solutions (HABITS) at the University of Maryland, Baltimore ${ }^{(14)}$. As recommended, the Yesple sum of statements was applied corresponding to each stage of change divided by the number of questions; later on the results of contemplation stages, action, and maintenance were summed up and then subtracted from the result of the precontemplation stage. Scores lower than or equal to 8.0 indicates that the individual is in pre-contemplation stage; 8.1-11.0, in contemplation stage; $11.1-14.0$, in action stage; and equal to or greater than 14.1, in maintenance stage ${ }^{(7,14)}$.

\section{Data analysis}

The result of URICA-VOICE questionnaire was considered as dependent variable, which as dichotomized into precontemplation and contemplation stages.

Independent variables were divided into blocks:

- Block 1 - demographic and economic data: age, education, marital status, number of children, and income;

- Block 2 - occupational data: teaching experience, work shifts, average number of students per class, perception of noise in classroom, school, out of school, and ventilation;

- Block 3 - lifestyle: hydration during lessons, water intake per day, fruit juice intake, amount of juice per day, physical activity, frequency of alcohol intake, alcoholic doses when drinking, and smoking;

- Block 4-health: treatment for gastroesophageal reflux, medical diagnosis of respiratory allergy, perception of breathing problem, and use of medication for diseases (hypertension, diabetes, depression or anxiety, sleep disturbances, rheumatism, etc.);

- Block 5 - voice: voice changes (hoarseness, dry throat, vocal fatigue, throat clearing, voice fails, vocal effort, pain when speaking, sore throat, etc.), voice use in daily life, sick leave for vocal problems, and default due to voice problems; and

- Block 6 - health care: medical consultations due to voice problems and speech therapy.

Statistical analysis was made with the Predictive Analytics SoftWare application (PASW® STATISTIC), version 18.0. Afterward, the bivariate analysis was done using the $\chi^{2}$-test of all dichotomized independent variables and the outcome variable. Those presenting descriptive level $\mathrm{p} \leq 0.20$ were selected for the logistic regression, which identified the variables associated with readiness to change.

This research was approved by the Research Ethics Committee of Universidade Estadual de Montes Claros (Unimontes) under Number 2889/11. All participants signed the informed consent before answering the questionnaire.

\section{RESULTS}

At first, a prevalence of self-reported voice problems was verified. In total, 226 teachers answered the questionnaire and $61.1 \%$ reported having voice problems. Of the 138 who provided affirmative answers, $58.0 \%$ had a change starting in up to 3 weeks before acute problem and $42.0 \%$, a change over 3 weeks before chronic problem. As stated in the guideline of the American Academy of Otolaryngology-Head and Neck Surgery Foundation ${ }^{(15)}$, acute changes are those lasting less than 3 weeks.

Age of all 138 participants ranged from 26 to 54 years, with mean age of 41.4 years and standard deviation (SD) of 5.6. Number of children varied from 0 to 5, with mean of 1.9 ( $\mathrm{SD} \pm 1.1$ ). The number of family members varied from 1 to 10 , with mean of $4.0(\mathrm{SD} \pm 1.3)$. Teaching experience varied from 1 year and 6 months to 29 years, with mean of 16 years and 5 months ( $\mathrm{SD} \pm 6$ years and 4 months). The minimum number of students per classroom was 17 and the maximum was 40 , with mean of $25.9(\mathrm{SD} \pm 4.0)$. Main characteristics of the sample are shown in Tables 1 and 2.

With respect to teachers' distribution according to readiness to change, based on URICA-VOICE scale, $59.4 \%$ were in pre-contemplation stage; $37.0 \%$ in contemplation stage; $3.6 \%$ in action stage; and no one was in the maintenance stage. The level of readiness to change was in the score ranging from 1.4 to 12.5 , with mean of 7.4 points $(\mathrm{SD} \pm 2.1)$.

Considering that only five teachers were in the action stage, they were excluded from other statistical analyses. They reported voice problems for over a month, and three of them said they had sought speech therapy. One of them mentioned not having sought a speech therapist because the only symptom was sore throat and she believed it was a result of hypothyroidism.

The variable outcome was considered in two categories: pre-contemplation and contemplation. $65.0 \%$ of teachers with acute voice problems were in the pre-contemplation stage and $35.0 \%$ were in the contemplation stage; among those with chronic voice problem, $56.6 \%$ were in the precontemplation stage and $43.4 \%$ in the contemplation stage $(\mathrm{p}=0.330)$.

The bivariate analysis between the main group characteristics and the two stages for behavioral change by URICAVOICE scale is presented in Table 3.

Table 4 shows the variables in the final model of statistical multivariate analysis. Those who reported using medication, failed to realize voice problems, or did/were doing speech therapy are more likely to present readiness for behavior change. 
Table 1. Sociodemographic, economic, occupational, and lifestyle data of 138 teachers with voice problems allocated in public schools, Montes Claros, Minas Gerais, 2013

\begin{tabular}{|c|c|c|}
\hline Variáveis & $\mathrm{n}$ & $\%$ \\
\hline \multicolumn{3}{|l|}{ Age group } \\
\hline $26-29$ & 4 & 2.9 \\
\hline 30-39 & 44 & 31.9 \\
\hline $40-49$ & 81 & 58.7 \\
\hline $50-54$ & 9 & 6.5 \\
\hline \multicolumn{3}{|l|}{ Marital status } \\
\hline Single & 20 & 14.5 \\
\hline Married & 98 & 71.0 \\
\hline Divorced & 17 & 12.3 \\
\hline Widow & 3 & 2.2 \\
\hline \multicolumn{3}{|l|}{ School } \\
\hline Higher education and postgraduation & 62 & 44.9 \\
\hline Higher education without postgraduation & 73 & 52.9 \\
\hline Secondary school & 3 & 2.2 \\
\hline \multicolumn{3}{|l|}{ Number of children } \\
\hline None & 20 & 14.5 \\
\hline One or more & 118 & 85.5 \\
\hline \multicolumn{3}{|l|}{ Family income } \\
\hline$\geq \mathrm{R} \$ 2,500.00$ & 44 & 31.9 \\
\hline$<\mathrm{R} \$ 2,500.00$ & 94 & 68.1 \\
\hline \multicolumn{3}{|l|}{ Teaching experience (years) } \\
\hline$\leq 16$ & 48 & 34.8 \\
\hline$>16$ & 90 & 65.2 \\
\hline \multicolumn{3}{|l|}{ Number of students in class } \\
\hline$\leq 25$ & 75 & 54.3 \\
\hline$>25$ & 63 & 45.7 \\
\hline \multicolumn{3}{|l|}{ Noise in class } \\
\hline Not important & 3 & 2.2 \\
\hline Tolerable & 88 & 63.8 \\
\hline Uncomfortable & 44 & 31.8 \\
\hline Unbearable & 3 & 2.2 \\
\hline \multicolumn{3}{|l|}{ Noise in school } \\
\hline Not important & 7 & 5.1 \\
\hline Tolerable & 83 & 60.1 \\
\hline Uncomfortable & 43 & 31.2 \\
\hline Unbearable & 5 & 3.6 \\
\hline \multicolumn{3}{|l|}{ Noise out of school } \\
\hline Not important & 46 & 33.3 \\
\hline Tolerable & 75 & 54.3 \\
\hline Uncomfortable & 16 & 11.6 \\
\hline Unbearable & 1 & 0.8 \\
\hline \multicolumn{3}{|l|}{ Ventilation in class } \\
\hline Satisfactory & 14 & 10.1 \\
\hline Reasonable & 58 & 42.0 \\
\hline Poor & 46 & 33.3 \\
\hline Very poor & 20 & 14.6 \\
\hline \multicolumn{3}{|l|}{ Water intake during classes } \\
\hline Yes & 100 & 72.5 \\
\hline No & 38 & 27.5 \\
\hline \multicolumn{3}{|l|}{ Amount of water/day } \\
\hline$\geq 4$ glasses & 75 & 54.3 \\
\hline 1-3 glasses & 63 & 45.7 \\
\hline \multicolumn{3}{|l|}{ Alcohol intake } \\
\hline Never & 67 & 48.6 \\
\hline Monthly or less & 37 & 26.8 \\
\hline $2-4$ times per month & 29 & 21.0 \\
\hline 2-3 times per week & 5 & 3.6 \\
\hline \multicolumn{3}{|l|}{ Smoking } \\
\hline Nonsmoker & 123 & 89.1 \\
\hline Former smoker & 10 & 7.2 \\
\hline Smoker & 5 & 3.6 \\
\hline Physical activity & & \\
\hline Yes & 49 & 35.5 \\
\hline No & 89 & 64.5 \\
\hline
\end{tabular}

Table 2. Health and vocal problems of 138 teachers with vocal disorders from the municipal network, Montes Claros, Minas Gerais, 2013

\begin{tabular}{|c|c|c|}
\hline Variables & $\mathrm{n}$ & $\%$ \\
\hline \multicolumn{3}{|c|}{ Gastroesophageal reflux } \\
\hline No & 127 & 92.0 \\
\hline Yes & 11 & 8.0 \\
\hline \multicolumn{3}{|c|}{ Diagnosis of respiratory allergy } \\
\hline No & 89 & 64.5 \\
\hline Yes & 49 & 35.5 \\
\hline \multicolumn{3}{|c|}{ Perception of respiratory disorder } \\
\hline No & 75 & 54.3 \\
\hline Yes & 63 & 45.7 \\
\hline \multicolumn{3}{|l|}{ Use of medication } \\
\hline No & 98 & 71.0 \\
\hline Yes & 40 & 29.0 \\
\hline \multicolumn{3}{|l|}{ Hypertension } \\
\hline No & 123 & 89.1 \\
\hline Yes & 15 & 10.9 \\
\hline \multicolumn{3}{|l|}{ Diabetes } \\
\hline No & 137 & 99.3 \\
\hline Yes & 1 & 0.7 \\
\hline \multicolumn{3}{|l|}{ Sleep disorders } \\
\hline No & 129 & 93.5 \\
\hline Yes & 9 & 6.5 \\
\hline \multicolumn{3}{|l|}{ Hoarseness } \\
\hline No & 47 & 34.1 \\
\hline Yes & 91 & 65.9 \\
\hline \multicolumn{3}{|l|}{ Sore throat } \\
\hline No & 61 & 44.2 \\
\hline Yes & 77 & 55.8 \\
\hline \multicolumn{3}{|l|}{ Fatigue when speaking } \\
\hline No & 66 & 47.8 \\
\hline Yes & 72 & 52.2 \\
\hline \multicolumn{3}{|l|}{ Presence of catarrh } \\
\hline No & 67 & 48.6 \\
\hline Yes & 71 & 51.4 \\
\hline \multicolumn{3}{|l|}{ Voice failure } \\
\hline No & 86 & 62.3 \\
\hline Yes & 52 & 37.7 \\
\hline \multicolumn{3}{|l|}{ Vocal effort } \\
\hline No & 98 & 71.0 \\
\hline Yes & 40 & 29.0 \\
\hline \multicolumn{3}{|l|}{ Pain when speaking } \\
\hline No & 129 & 93.5 \\
\hline Yes & 9 & 6.5 \\
\hline \multicolumn{3}{|c|}{ Vocal signs and symptoms } \\
\hline$<4$ symptoms & 75 & 54.3 \\
\hline$\geq 4$ symptoms & 63 & 45.7 \\
\hline \multicolumn{3}{|c|}{ Use of voice in daily routine } \\
\hline Speaks little & 1 & 0.7 \\
\hline Speaks moderately & 13 & 9.4 \\
\hline Speaks a lot & 83 & 60.2 \\
\hline Speaks too much & 41 & 29.7 \\
\hline Leave by vocal disorde & & \\
\hline No & 109 & 79.0 \\
\hline Yes & 29 & 21.0 \\
\hline Default due to vocal dis & & \\
\hline No & 94 & 68.1 \\
\hline Yes & 44 & 31.9 \\
\hline Medical assistance du & & \\
\hline No & 69 & 50.0 \\
\hline Yes & 69 & 50.0 \\
\hline Speech therapy & & \\
\hline No & 108 & 78.3 \\
\hline Yes & 30 & 21.7 \\
\hline
\end{tabular}




\section{DISCUSSION}

The prevalence of self-reported voice disorders was similar to those found in other studies $(60.0 \text { and } 64.8 \%)^{(16,17)}$, but above the prevalences of $11.6 \%$ to the national extent ${ }^{(11)}$ and $47.6 \%$ in Florianopolis, Santa Catarina ${ }^{(18)}$, and below a study conducted in Maceio, Alagoas, whose prevalence of dysphonia was $87.3 \%^{(19)}$. This variation is probably due to differences in methodology between these studies.
In this study, the readiness for behavior change among teachers of municipal schools who reported dysphonia was proved low in relation to voice care. At first, a rating was not found that quantifies how much the observed result in Transtheoretical Model studies is satisfactory in the literature. However, a larger number of people in more advanced stages in URICA-VOICE stage were expected due to the high prevalence of dysphonia among teachers. Low readiness to change may result from two factors:

Table 3. Association between stages of pre-contemplation and contemplation according to URICA-VOICE scale and independent variables

\begin{tabular}{|c|c|c|c|}
\hline \multirow[b]{2}{*}{ Variables } & \multicolumn{2}{|c|}{ Stages } & \multirow[b]{2}{*}{$p$-value* } \\
\hline & $\begin{array}{c}\text { Pre-contemplation } \\
\mathrm{n}(\%) \\
\end{array}$ & $\begin{array}{c}\text { Contemplation } \\
\mathrm{n}(\%) \\
\end{array}$ & \\
\hline \multicolumn{4}{|c|}{ Sociodemographic, economic, occupational data } \\
\hline \multicolumn{4}{|c|}{ Age (years) } \\
\hline$<40$ & $28(60.9)$ & $18(39.1)$ & 0.892 \\
\hline$\geq 40$ & $54(62.1)$ & $33(37.9)$ & \\
\hline \multicolumn{4}{|l|}{ Marital status } \\
\hline With partner & $59(62.8)$ & $35(37.2)$ & 0.682 \\
\hline Without partner & $23(59.0)$ & $16(41.0)$ & \\
\hline \multicolumn{4}{|l|}{ Children } \\
\hline None & $12(60.0)$ & $8(40.0)$ & 0.864 \\
\hline One or more & $70(61.9)$ & $43(38.1)$ & \\
\hline \multicolumn{4}{|l|}{ Income } \\
\hline$\geq \mathrm{R} \$ 2,500.00$ & $24(54.5)$ & $20(45.5)$ & 0.236 \\
\hline$<R \$ 2,500.00$ & $58(65.2)$ & $31(34.8)$ & \\
\hline \multicolumn{4}{|l|}{ Schooling } \\
\hline Postgraduation & $37(62.7)$ & $22(37.3)$ & 0.823 \\
\hline No postgraduation & $45(60.8)$ & $29(39.2)$ & \\
\hline \multicolumn{4}{|l|}{ Teaching experience (years) } \\
\hline$\leq 16$ & $29(63.0)$ & $17(37.0)$ & 0.811 \\
\hline$>16$ & $53(60.9)$ & $34(39.1)$ & \\
\hline \multicolumn{4}{|l|}{ Number of students } \\
\hline$\leq 25$ & $48(65.8)$ & $25(34.2)$ & 0.284 \\
\hline$>25$ & $34(56.7)$ & $26(43.3)$ & \\
\hline \multicolumn{4}{|l|}{ Noise in class } \\
\hline Not important to tolerable & $58(65.9)$ & $30(34.1)$ & $0.158^{*}$ \\
\hline Uncomfortable to unbearable & $24(53.3)$ & $21(46.7)$ & \\
\hline \multicolumn{4}{|l|}{ Noise out of school } \\
\hline Not important to tolerable & $73(61.3)$ & $46(38.7)$ & 0.830 \\
\hline Uncomfortable to unbearable & $9(64.3)$ & $5(35.7)$ & \\
\hline \multicolumn{4}{|l|}{ Ventilation in class } \\
\hline Satisfactory to reasonable & $48(67.3)$ & $23(32.4)$ & $0.131^{*}$ \\
\hline Poor to very poor & $34(54.8)$ & $28(45.2)$ & \\
\hline \multicolumn{4}{|l|}{ Lifestyle } \\
\hline \multicolumn{4}{|l|}{ Water intake/day } \\
\hline$\geq 4$ glasses & $40(55.6)$ & $32(44.4)$ & $0.116^{*}$ \\
\hline$<4$ glasses & $42(68.9)$ & $19(31.1)$ & \\
\hline \multicolumn{4}{|l|}{ Smoking } \\
\hline Nonsmoker & $69(58.5)$ & $49(41.5)$ & $0.034^{*}$ \\
\hline Smoker/former smoker & $13(86.7)$ & $2(13.3)$ & \\
\hline \multicolumn{4}{|l|}{ Physical activities } \\
\hline Yes & $28(58.7)$ & $20(41.7)$ & 0.554 \\
\hline No & $54(63.5)$ & $31(36.5)$ & \\
\hline
\end{tabular}


Table 3. Continuation

\begin{tabular}{|c|c|c|c|}
\hline \multirow[b]{2}{*}{ Variables } & \multicolumn{2}{|c|}{ Stages } & \multirow[b]{2}{*}{$p$-value } \\
\hline & $\begin{array}{c}\text { Pre-contemplation } \\
\mathrm{n}(\%)\end{array}$ & $\begin{array}{c}\text { Contemplation } \\
\mathrm{n}(\%)\end{array}$ & \\
\hline \multicolumn{4}{|l|}{ Health } \\
\hline \multicolumn{4}{|l|}{ Gastroesophageal reflux } \\
\hline No & $79(64.8)$ & $43(35.2)$ & $0.014^{*}$ \\
\hline Yes & $3(27.3)$ & $8(72.7)$ & \\
\hline \multicolumn{4}{|c|}{ Diagnosis of respiratory allergy } \\
\hline No & $57(66.3)$ & $29(33.7)$ & $0.138^{*}$ \\
\hline Yes & $25(53.2)$ & $22(46.8)$ & \\
\hline \multicolumn{4}{|l|}{ Use of medication } \\
\hline No & $65(68.4)$ & $30(31.6)$ & $0.011^{*}$ \\
\hline Yes & $17(44.7)$ & $21(55.3)$ & \\
\hline \multicolumn{4}{|l|}{ Hypertension } \\
\hline No & $77(64.7)$ & $42(35.3)$ & $0.035^{\star}$ \\
\hline Yes & $5(35.7)$ & $9(64.3)$ & \\
\hline \multicolumn{4}{|l|}{ Diabetes } \\
\hline No & $82(62.1)$ & $50(37.9)$ & 0.203 \\
\hline Yes & $0(0.0)$ & $1(100.0)$ & \\
\hline \multicolumn{4}{|l|}{ Sleep disorders } \\
\hline No & $79(63.2)$ & $46(36.8)$ & $0.147^{\star}$ \\
\hline Yes & $3(37.5)$ & $5(62.5)$ & \\
\hline \multicolumn{4}{|l|}{ Voice } \\
\hline \multicolumn{4}{|l|}{ Hoarseness } \\
\hline No & $29(63.0)$ & $17(37.0)$ & 0.811 \\
\hline Yes & $53(60.9)$ & $34(39.1)$ & \\
\hline \multicolumn{4}{|l|}{ Failure } \\
\hline No & $59(69.4)$ & $26(30.6)$ & $0.014^{*}$ \\
\hline Yes & $31(62.0)$ & $19(38.0)$ & \\
\hline \multicolumn{4}{|l|}{ Presence of catarrh } \\
\hline No & $43(68.3)$ & $20(31.7)$ & $0.138^{*}$ \\
\hline Yes & $39(55.7)$ & $31(44.3)$ & \\
\hline \multicolumn{4}{|l|}{ Fatigue when speaking } \\
\hline No & $43(68.3)$ & $20(31.7)$ & $0.138^{*}$ \\
\hline Yes & $39(55.7)$ & $31(44.3)$ & \\
\hline \multicolumn{4}{|l|}{ Effort to speak } \\
\hline No & $63(85.6)$ & $33(34.4)$ & $0.129^{*}$ \\
\hline Yes & $19(51.4)$ & $18(48.6)$ & \\
\hline \multicolumn{4}{|l|}{ Pain when speaking } \\
\hline No & $71(65.7)$ & 37 (34.3) & $0.044^{*}$ \\
\hline Yes & $11(44.0)$ & $14(56.0)$ & \\
\hline \multicolumn{4}{|l|}{ Ardor in throat } \\
\hline No & $58(64.4)$ & $32(35.6)$ & 0.338 \\
\hline Yes & $24(55.8)$ & $19(44.2)$ & \\
\hline \multicolumn{4}{|l|}{ Self-reported voice disorder } \\
\hline$<4$ & $52(70.3)$ & $22(29.7)$ & $0.022^{*}$ \\
\hline$\geq 4$ & $30(50.8)$ & $29(49.2)$ & \\
\hline Use of voice in daily routine & & & \\
\hline Speaks little/moderately & $9(64.3)$ & $5(35.7)$ & 0.830 \\
\hline Speaks a lot/too much & $73(61.3)$ & $46(38.7)$ & \\
\hline Health assistance due to voic & & & \\
\hline Medical appointment due to & & & \\
\hline Yes & $33(50.0)$ & $33(50.0)$ & $0.006^{*}$ \\
\hline No & 49 (73.1) & $18(26.9)$ & \\
\hline Speech therapy & & & \\
\hline Yes & $11(40.7)$ & $16(59.3)$ & $0.012^{*}$ \\
\hline No & $71(67.0)$ & $35(33.0)$ & \\
\hline
\end{tabular}

${ }^{*} \chi^{2}$-test 
Table 4. Multivariate analysis for factor associated with readiness to change behavior among teachers with complaint of dysphonia, Montes Claros, Minas Gerais, 2013

\begin{tabular}{lcc}
\hline Variables & p-value & Adjusted OR $(95 \% \mathrm{Cl})^{\star}$ \\
\hline Use of medication & 0.006 & $3.30(1.40-7.74)$ \\
Voice failure & 0.048 & $2.23(1.01-4.96)$ \\
Speech therapy & 0.015 & $3.25(1.25-8.43)$ \\
\hline
\end{tabular}

*Backward logistic regression: LR

Caption: $\mathrm{OR}=$ odds ratio; $95 \% \mathrm{Cl}=95 \%$ confidence interval

1. participants are aware of the existence of a problem to be faced, but are not well oriented to the consequences of this behavior; and

2. participants are trying to change behavior, but have no ability or support to do $\mathrm{so}^{(20)}$.

Individuals in the pre-contemplation stage are often characterized as resistant to change, unmotivated, and not ready to attend therapeutic or health-promotion programs. A possible explanation for this attitude is that traditional health-promotion programs are probably not good motivators to meet their needs ${ }^{(3)}$.

Some teachers were in the contemplation stage, which means that they intended to change behavior, perhaps because they recognize the positive aspects of such action. Five teachers with chronic dysphonia were in the action stage, that is, they were developing new behaviors.

Study conducted with 66 patients under dysphonia treatment in University hospitals of voice clinics at two educational institutions of Speech Therapy found 30.3\% of patients in the pre-contemplation stage, $57.6 \%$ in the contemplation stage, $12.1 \%$ in stage action, and none in the maintenance stage $\mathrm{e}^{(7)}$. This difference related to this study, or higher percentage in the stages of contemplation and action, can be attributed to the fact that individuals were under speech therapy; therefore, they presented higher levels of motivation.

In the analysis of this study, comparing the two stages, the variables associated with a greater predisposition/awareness (contemplation stage) for behavior change as to the voice were: use of medication, perception of voice failures, and demand for speech therapy. Conceivably, such factors may contribute to the vocal problem awareness, interfering in readiness to behavior change, reaching the contemplation stage.

The search for treatment was associated with voice complaint, although most participants were in the pre-contemplation stage and search for assistance usually occurs in more advanced readiness stages, when the individual considered solving his vocal problem already. Therefore, further studies are needed for a better understanding of these results.

Information about the patients' perception of their own voice help guide the therapy and can help increase the awareness of behavior change necessity. A possible strategy for individuals in the pre-contemplation stage would be to customize information about the negative impacts of dysphonia in quality of life and the benefits of speech therapy. Educational programs are basic conditions whose main purpose should be the empowerment of the individual and the community.

For those who are in the contemplation stage, they should motivate them, encouraging them to make specific plans ${ }^{(9)}$. Note that many can remain in this stage for long periods of time, the so-called chronic contemplation ${ }^{(20)}$. An activity for patients with vocal problems who are undergoing treatment would be voice recording during speech therapy process, which could be a valuable resource to encourage the patient, because this would motivate them to realize the progressive improvement of their voice. Due to lack of resources in outpatient public services, such recordings are limited to the beginning or end of treatment ${ }^{(7)}$.

The transition from a behavioral change stage to another depends on appropriate strategies and interventions in each specific moment. The Transtheoretical Model has ten change processes applicable to specific stages, and focuses on these activities so that progress can occur ${ }^{(3)}$.

It must be noted that the results of this study should be interpreted based on some of their limitations. Some of these limitations refer to the target audience, which were restricted to teachers in municipal public education, teaching from first to fifth grade. Others refer to be highlighted as concerned to the detection of voice problems, for they were measured by self-reported vocal complaints. It is important to note that the group was not made up of individuals enrolled in therapy programs, and the Transtheoretical Model has been mainly used to measure the dimensions of readiness to change in individuals under treatment.

Despite limitations, the importance of the topic and the lack of literature on the subject highlight the magnitude of the problem and the need for studies in the area. Results should motivate health-promotion activities to improve quality of life as to voice care and general health, which is a commitment of the speech therapist ${ }^{(21)}$. The Transtheoretical Model is an opportunity for the professional to work with health-promotion habits and to verify that each stage requires specific actions for adherence to vocal care.

\section{CONCLUSION}

Most teachers with vocal complaints are in the precontemplation stage in URICA-VOICE scale. This shows the need for an education process aimed to the risks of voice misuse and abuse, and to presenting the benefits of general and vocal health. Variables associated with readiness for behavior change are related to medication use, perceived voice failure, and the search for speech therapy. These results may support public health interventions involving people at different stages of the decision-making process as to behavioral change for vocal health.

\section{ACKNOWLEDGMENT}

We thank professors for their availability to participate and to Fundação de Amparo à Pesquisa do Estado de Minas Gerais (FAPEMIG) for the doctor degree scholarship. 
* LARRB was responsible for data collection and analysis, and writing of the paper; $A P C$ and ACCG oriented each phase of the research and provided the final review of the paper.

\section{REFERENCES}

1. Brasil. Ministério da Saúde. Secretaria de Vigilância em Saúde [Internet]. Vigilância em saúde no SUS: fortalecendo a capacidade de resposta aos velhos e aos novos desafios. Brasília: Ministério da Saúde; 2006 [cited 2013 Aug 23]. Available from: http://www.livrosgratis.com.br/arquivos_ livros/ms000273.pdf

2. Davies M, Macdowall W. Health Promotion Theory. London: Open University Press; 2006.

3. Glanz K, Rimer BK, Viswanath K. Health behavior and health education: theory, research and practice. $4^{\text {th }}$ ed. San Francisco: Jossey-Bass; 2008.

4. Toral N, Slater B. Abordagem do modelo transteórico no comportamento alimentar. Ciênc Saúde Coletiva. 2007;12(6):1641-50.

5. Souza CC, Silva JG, Oliveira MS, Bittencourt SA, Freire SD. Jogo patológico e motivação para mudança de comportamento. Psicol Clin. 2009;21(2):345-61.

6. Norcross JC, Krebs PM, Prochaska JO. Stages of change. J Clin Psychol. 2011;67(2):143-54.

7. Teixeira LC, Rodrigues AL, Silva AF, Azevedo R, Gama ACC, Behlau M. The use of the URICA-VOICE questionnaire to identify the stages of adherence to voice treatment. Codas. 2013;25(1):8-15.

8. Van Leer EV, Hapner ER, Connor NP. Transtheoretical model of health behavior change applied to voice therapy. J Voice. 2008;22(6):688-98.

9. National Institutes of Health [Internet]. Theory at a Glance: a guide for health promotion practice. US Department of Health and Human Services; 2005 [cited 2012 jan 31]. Available from: http://www.med. upenn.edu/chbr/documents/TheoryataGlance.pdf
10. Souza CC, Silva JG, Oliveira MS. Motivação para mudança de comportamento em amostra de jogadores patológicos. J Bras Psiquiatr. 2011;60(2):73-9.

11. Behlau M, Zambon F, Guerrieri AC, Roy N. Epidemiology of voice disorders in teachers and nonteachers in Brazil: prevalence and adverse effects. J Voice. 2012;26(5): 665.e9-18.

12. Simões-Zenari M, Bitar ML, Nemr NK. The effect of noise on the voice of preschool institution educators. Rev Saúde Pública. 2012;46(4):65764. [Portuguese].

13. Moraes ABA, Rolim GS, Costa Jr AL. O processo de adesão numa perspectiva analítico comportamental. Rev Bras Ter Comport Cogn. 2009;11(2):329-45.

14. The HABITS Lab at UMBC [Internet]. University of Rhode Island Change Assessment Scale: URICA [cited 2013 Mar 18]. Available from: http://habitslab.umbc.edu/the-model/

15. Schawartz SR, Cohen SM, Dailey SH, Rosenfeld RM, Deutsch ES, Gillespie MB, et al. Clinical practice guideline: hoarseness (dysphonia). Otolaryngol Head Neck Surg. 2009;141(3 Suppl 2):S1-S31.

16. Ferreira LP, Latorre MRDO, Giannini SPP. A violência na escola e os distúrbios de voz de professores. Distúrb Comun. 2011;23(2):165-72.

17. Caporossi C, Ferreira LP. Sintomas vocais e fatores relativos ao estilo de vida em professores. Rev CEFAC. 2011;13(1):132-9.

18. Marçal CCB, Peres MA. Alteração vocal auto-referida em professores: prevalência e fatores associados. Rev Saúde Pública. 2011;45(3):503-11.

19. Alves LP, Araújo LTR, Xavier Neto JA. Prevalência de queixas vocais e estudo de fatores associados em uma amostra de professores de ensino fundamental em Maceió, Alagoas, Brasil. Rev Bras Saúde Ocup. 2010;35(121):168-75.

20. Miller RW, Rollnick S. Entrevista motivacional: preparando as pessoas para a mudanças de comportamentos adictivos. Porto Alegre: ArtMed; 2001.

21. Alves LA, Robazzi MLCC, Marziale MHP, Felippe ACN, Romano CC. Alterações da saúde e a voz do professor, uma questão de saúde do trabalhador. Rev Latino-Am Enfermagem. 2009;17(4):566-72. 